\title{
Public Sculpture and Social Practice in the Roman Empire
}

\author{
Elizabeth Wolfram Thill (IUPUI)
}

In press. In The Oxford Handbook of Roman Imagery and Iconography, edited by N. Elkins and L. Cline. New York: Oxford University Press.

The Mausoleum of the Haterii in Rome was once covered with relief sculpture, including representations of magnificent public buildings built under the Flavian emperors (Museo Gregoriano Profano nos. 9997, 9998; Leach 2006; figure 1). The mausoleum was thus a building covered in sculpture that itself depicted buildings covered in sculpture. On a basic level the Haterii Mausoleum bears witness to the sculptural abundance that once suffused the lives of inhabitants of Roman cities (Kellum 2015; Longfellow 2015). On a more complex level, the mausoleum also bears witness to the importance of those sculptures for the ancient conception of imperial architecture. The increasingly elaborate public buildings and spaces built under the emperors not only served as architectural marvels but also as expanded sculptural venues (Longfellow 2015). Indeed, public sculpture was one of the main lines of communication between rulers and ruled in the Roman Empire.

Because of its prominence, ubiquity, and communicative role, public sculpture was an important force in disseminating and shaping the iconography that inhabitants of Roman cities encountered. To be understood, public sculpture relied on a vast array of imagery that did more than just illustrate the sculpture's subject but instead spoke about that subject. Public sculpture incorporated iconography found in other media, such as coins and sarcophagi, and introduced or proliferated new iconographical motifs, as in the representation of the adventus, or ceremonial return of the emperor to Rome (figure 2). 
Despite numerous inherent difficulties, scholars of Roman art are making strides in exploring how sculpture affected the lives of ancient viewers. Traditionally classical archaeology and art history have been focused on the patrons and artists (who?) or subjects (what or when?) of painting and sculpture. More recently scholars have turned their attention to questions of intent, message, and audience; in other words, the "why?" and "what then?" Theoretical approaches that explore issues of reception and viewers constitute a particularly flourishing field (for prominent examples, see e.g. Elsner 1995, Clarke 2003; for general discussion and bibliography see Mazurek 2016, Cassibry 2018; for a methodological introduction see Trimble 2015). The time is ripe to move Roman sculptures out of the museum theoretically and back into the lives of the people who lived with them.

\section{Reception and Monumental Reliefs}

Appreciating how ancient Romans perceived and utilized public sculpture is a challenge on many levels. Perhaps the most insidious obstacle is that ancient attitudes towards sculpture are so divergent from modern lines, both popular and academic. Even Roman conceptions of ideas such as "private" or "public" do not map well onto conventional modern meanings. The often elaborate exterior sculpture on privately owned tombs such as that of the Haterii family were designed to attract the attention of a public audience (Wrede 1981; Fejfer 2008). Similarly, the sculptures within privately owned elite houses often served as the backdrops to what would be considered "public" business in the modern sense (Warden 1991; Severy 2000 322-323; Gazda 2015). The Roman experience of "public sculpture” was thus much broader, pervasive, and more fluid than one might expect. 
In this chapter I take a contextual approach, defining "public sculpture" as sculpture set up in officially managed space (presumably) accessible to the general population. Although the specific provenience of most sculpture is unknown, factors inherent to the sculpture itself, such as scale, physical design, or subject matter, can allow a reasonable guess as to general setting. Public sculpture, thus defined, took two main forms: freestanding sculpture and architectural reliefs. This chapter will focus on the latter, as a lens through which we can explore various issues relevant to understanding how people related to public sculpture in imperial Rome. Specifically I will concentrate on monumental reliefs, or large-scale relief sculptures set up on publically accessible structures, by persons acting in the capacity of official positions of authority (Sobocinski and Wolfram Thill 2015). ${ }^{1}$

This focus on monumental reliefs has several motivations. In the immediate context of this volume, monumental reliefs are the main genre that distinguishes sculptural experience in Rome under the principate from that of other periods and regions, covered in chapters 9 and 11, respectively. From a broader perspective, the reception of freestanding public sculpture already has been the subject of numerous thorough investigations (e.g. Gazda 1995; Stewart 2003; 2008; Madigan 2012; Shaya 2013; Gensheimer 2018; Longfellow and Perry 2018). Less attention has been devoted specifically to the study of how audiences experienced monumental reliefs, with notable exceptions (Beckmann 2002; 2011; Clarke 2003, 19-67; Elsner 2005; Hughes 2014). This chapter presents an opportunity to touch briefly on the numerous questions raised when considering public sculpture in general and monumental reliefs in particular from reception or social practice perspectives.

\footnotetext{
${ }^{1}$ Traditionally such sculptures are referred to as "historical" or "state" reliefs. For methodological critique of these terms, see Hölscher 2015: 37; Sobocinski and Wolfram Thill 2015: 276-279.
} 
Monumental reliefs have several advantages as a means for studying public sculptural practice. The first is that they are geographically delimited. The size of the sculptures, as manifested in sheer weight, suggests that reliefs did not move between cities, although they could be moved around within a city, as we will see. The vast majority of monumental reliefs have been found in or near the city of Rome. While it is admittedly problematic to extrapolate ancient production rates of reliefs from recovered examples, the discrepancy between capital and provinces is so stark that it can be taken as meaningful. This already tells us something important about the audience of monumental reliefs as a genre, namely that this audience was associated with the capital city.

What is more, the scale of monumental reliefs, considered as evidence of the cost and organization involved, indicates some sort of official commission, and thus public setting. This impression is reinforced by the few in situ monuments we have, all of which stood in major public gathering spaces or along main roads. As relief monuments, the sculptures must have been connected intimately to architecture, although unfortunately the common loss of specific context creates numerous methodological challenges (Sobocinski and Wolfram Thill 2015, 283-286). Nevertheless, the sculptures themselves reveal that their ultimate audience was large and relatively unrestricted. This makes it important to always keep in mind the idea that different subsets of a monument's audience might understand, intentionally or not, various aspects of a monument in different ways.

Monumental reliefs are also delimited chronologically. Although the earliest monumental reliefs to survive date to the late Republican period, the phenomenon appears limited, with only three monuments extant (Sobocinski and Wolfram Thill 2015, 280). By the end of the first century $\mathrm{CE}$, in contrast, figural reliefs had become a prevalent form of public communication, 
with some building types undergoing alterations to maximize their potential for sculptural display (Hölscher 2009). The production of monumental reliefs slowed drastically in the third century, with the occasional monument erected in Rome or other large city as the primacy of Rome diminished. The prevalence of structures carrying monumental reliefs therefore was a unique and characteristic feature of sculptural practice in Rome at the height of power.

\section{Sending the Message}

Monumental reliefs shared a close but complicated relationship, both chronological and conceptual, with the emperor. This relationship can be traced back to the beginnings of the genre, in the Ara Pacis Augustae, or Altar of Peace, a monument dedicated in Rome around $9 \mathrm{BCE}$ (Pollini 2012; Rossini 2012). Set up on the Via Flaminia near Augustus' funerary complex, the large altar screen was covered in relief sculpture of various sizes and subjects. As we will see, the Ara Pacis embodied many features that would become common in later monumental reliefs. These include a focus on the emperor, the integration of reliefs into ideological programs, and a blend of historicizing and mythological features.

The Ara Pacis represents a birth of a trend, whereby monumental reliefs would increasingly focus on the emperor, both in terms of his activities and his person (although this trend as it regards composition may have been overemphasized in modern scholarship; Elsner 2000b). Augustus himself, along with various family members, appears in a religious procession of elites on the south exterior frieze of the Ara Pacis. He is made recognizable through subtle but distinctive portrait features, which set him off from the generalized Classical idealization of surrounding figures. 
Augustus' features on the Ara Pacis were a nascent example of what modern scholars term "portrait types," a phenomenon in which certain physiognomic features for the representation of important individuals were selected, codified, and replicated on a massive scale (Fittschen 1996; Rose 1997; Bartman 1999; Alexandridis 2004; Fittschen 2010). These types served three main iconographic purposes. They made possible the easy recognition of individuals, even without the aid of text. They conveyed ideological concepts about an individual; Augustus, for example, does not noticeably age in his decades of portraits, a feature having more to do with ideologies of renewal and fecundity than his physical appearance. Finally, standardized types made possible a production industry that disseminated the imperial image across the empire. This was not a minor operation: approximately 50,000 imperial statues are thought to have been produced under Augustus alone (Pfanner 1989, 178-179). What life events could occasion the creation and distribution of a new portrait type is still poorly understood, as are the mechanisms behind how new types arrived in the distant provinces.

The influence of imperial portraiture on ancient viewers is difficult to appreciate, especially since whole categories of portraits are effectively lost. The massive metal equestrian portraits that were the pinnacle of prestige are now represented by a single complete example, the Palazzo dei Conservatori Marcus Aurelius (Stewart 2012). Similarly, honorary arches such as those of Titus or Constantine are missing their crowning statue groups (figure 3). Such groups are the focus of much ancient interest, both written (Tabula Sierensis 1.9-21; Severy 2000, 3234) and visual (figure 4), although intriguingly they are often omitted in representations on monumental reliefs (figure 2). What we can say is that sculptural portraits, coupled with images on coins and other media, produced a world where the inhabitant of a Roman city was bombarded by standardized images of the imperial family. 
In Rome, the general omnipresence of the emperor was augmented by his appearance in monumental reliefs, which notably added historicized narrative contexts to his images. While free-standing portraiture tended to present the emperor as an almost abstract figure, in reliefs the emperor was cast as the protagonist in an (exaggerated and grandiose) human drama. This emphasis on a three-dimensional, historicized presentation of leadership was a distinctive feature of Roman monumental reliefs, without clear Etruscan or Greek precedents. The experience of a viewer in imperial Rome - surrounded by structures bearing representations of the emperor in action-was distinctive for the Classical world.

Because monumental reliefs feature highly detailed representations of imperial actions, scholars originally used them to supplement or illustrate the historical record. Researchers increasingly came to recognize, however, that far from documenting objective historical events, the reliefs presented carefully contrived imagery that was more interested in conveying political or ideological messages than in recreating the past. Even the deceptively straightforward processions of the Ara Pacis have proven impossible to connect to a single historical event (Rose 1990; Billows 1993; Rehak 2001). Approaches that incorporate iconology and semiotics, such as those pioneered by S. Settis (1988), T. Hölscher (1980; 2004) and J. Elsner (1991; 2000b; 2000a; 2005), are proving more productive, by calling attention to the layered intentions and meanings presented in what at first glance seem to be documentary narratives.

Unlike coins, monumental reliefs required recognition without the aid of labels. Reliefs thus increasingly relied on repeated scene types that presented the emperor in stereotyped actions. One example is the adventus, which featured the emperor returning on foot in the presence of divinities against an architectural backdrop (figure 2). Such iconography 
immortalized the emperor as a ruler who accomplished a type of action, even if an individual representation did not faithfully document any particular event.

Another characteristic feature of Roman monumental reliefs is the blending of historicizing, mythological, and purely symbolic elements. On the Ara Pacis, these different categories are separated on different parts of the monument. The long sides of the screen exterior present a religious procession of Rome's elites above a lower register of acanthus scrolls. The short sides, meanwhile, bear smaller mythological panels whose topics play into a wider Augustan ideology. On the west side the two panels are quasi-historical, illustrating founding myths for the historical city of Rome (Rehak 2001). The two east panels are purely symbolic, showing the goddess Roma and a much disputed fertility figure (figure 5) (Galinsky 1992; Spaeth 1994).

As monumental reliefs developed, these different categories of imagery became increasingly integrated, although the use of symbolic figures varied, even within close chronologies. The Column of Trajan (Coarelli 2000) presented primarily historicized scenes (battles, marching, and so forth) with the sparing use of symbolic figures: of the column's more than 2500 figures, only two, a river god (Scene 3) and the personification of Night (Scene 37), are divine. The Trajanic arch at Beneventum, in contrast, presents Trajan numerous times in the same scene as personifications, although the Olympic gods are kept in separate panels (Hassel 1966; Speidel 2005-2006). Similarly, the Column of Marcus Aurelius (Coarelli 2008) employs only two divine figures, a river god borrowed from the Column of Trajan (Scene 3) and a rain god (Scene 16; figure 6) apparently representing a historical miracle (Kovács 2009). Contemporary panels from a lost arch of Marcus Aurelius (Ryberg 1967; henceforth Marcus 
Aurelius Panels) show the emperor at times surrounded by divinities, including major gods such as Mars (figure 2).

On the Ara Pacis, the sculpture's imagery as a whole is integrated in a complex program of ideology, propagated in numerous media throughout Augustus' reign (Zanker 1988). Similar iconographical and ideological correspondence between monumental reliefs and other media can be seen in various periods. These correspondences, coupled with the genre's focus on the emperor, long led scholars to assume that relief monuments were closely overseen by the imperial court. The few in situ dedicatory inscriptions we have (e.g., the Trajanic Arch at Beneventum), however, specify that the monuments were erected as gifts to the emperor by the Senate and People of Rome (SPQR). Recent scholarship accordingly has interpreted these monuments as reflections of senatorial interests, more a means of communicating ideals of imperial rule than of documenting the emperor's activities as imposed from the palace (Marlowe 2004; Ewald and Noreña 2010; Hughes 2014).

\section{Receiving the Message}

Understanding how people might have reacted to monumental reliefs is a daunting, some might say impossible, task. Nevertheless, by sticking very close to the sculptures themselves, some critical observations can be made.

One of the most complex issues for monumental reliefs is that of visibility. Despite their wealth of detail, most sculpture in this genre could not be seen clearly or examined closely, given its position high above the ancient viewer. The figure of Night on the Column of Trajan, for instance, is barely discernible to an educated eye working with a modern telephoto lens. What is more, the modern viewer sees the column shorn of the narrow peristyle and other buildings that 
surrounded it, constricting access and further obstructing views of the monument (Galinier 2007). This issue of visibility is most apparent for the hundred foot columns, but would have been a factor, more or less, for much relief sculpture, including the upper tiers of honorary arches. This raises the vexing question of the purpose and intended audience of all that detail. Whatever that purpose was, it certainly was not the traditional use to which modern scholars have employed relief sculpture, namely the close examination of details from photographs in order to reconstruct ancient life.

There is little hard evidence for why the ancients conceived and put such care into details that no one could see, or how they conceptualized such monuments later (which has not stopped scholars from discussing the subject at length; see Wolfram Thill 2011, 285 for bibliography). The Columns of Trajan and Marcus Aurelius are an interesting case study for this issue, because the later column borrows numerous features from its predecessor, including the wealth of detail at considerable heights. On the one hand, M. Beckmann $(2011,26)$ has argued convincingly that the sculptors of the later column placed the Rain God Miracle (Scene 16; figure 6), the most famous event of the war, low on the shaft so that the scene was highly visible, but out of sync with any historical chronology. On the other hand, the Antonine designers increased the pedestal height, moving the sculpture four meters higher than for even the Trajanic Column (Wolfram Thill 2018b, 282-283). Visibility simply does not seem to have been a primary concern for the ancient producers of relief sculpture.

The issue of visibility raises interesting questions of intended audience. Some scholars have explained the wealth of inscrutable detail as a religious offering or as the product of extreme artistic pride; in other words, the intended audiences were the gods or the producers themselves. Neither explanation is fully satisfactory. As mentioned above, the dedicatory 
inscriptions clearly state the monument is a gift to the human emperor, and the ideological messages conveyed by the details (e.g., Rome's military superiority, barbarians as noble opponent) seem human, rather than divine, concerns. Artistic pride is an insufficient excuse for the coordination, time, and cost that all the details as whole entailed, inputs that would have had to have some official approval.

Two other possibilities may be more convincing. The first is that the senate or the emperor himself was the intended audience, with the sculpture available for inspection through temporary construction scaffolding (see Lancaster 1999 for such scaffolding). Another scenario, not necessarily exclusive, is that the lower visible sections of the reliefs were meant to be legible for a broad audience at ground level, and the upper parts just continued the same level of detail to maintain the appearance of a persistent, equally detailed record (e.g., Hölscher 2002, 140; Dillon 2006, 259). This theory is more applicable to the helical columns than to arches, where the sculptural subjects are not necessarily repeated or even consistent for the height of the monument. This also presupposes that the lower spirals of the columns were themselves visible in detail, which was not necessarily the case.

The problem of visibility exemplifies a phenomenon, whereby the modern scholar is left with the uncomfortable realization that the ancients simply did not think about public sculpture in a way that is familiar or convenient for modern interests. Ancient imperial portraits were less interested in preserving what a famous individual actually looked like, than they were in broadcasting messages about ideology and identity. Extant monumental reliefs obviously represent considerable investment of treasure, time, and artistic talent, yet not a single ancient written source mentions any monumental relief sculpture in Rome. The Column of Trajan is an excellent case study: while the modern bibliography on the helical frieze runs to thousands of 
pages, ancient references to the column focus on the interior spiral staircase without a single mention of the frieze (Beckmann 2002). Similarly coin representations carefully depict the crowning statue, but reduce the figural frieze to at best a single helical line, which may in fact also allude to the interior staircase (Claridge 1993, 15; figure 4). ${ }^{2}$ Indeed, even monumental reliefs themselves rarely include reliefs in their depictions of buildings (figure 2), although they are sometimes included on coins. Put simply, the monumental reliefs that have been so influential in modern Roman art history (Brendel 1979) are nearly invisible in ancient sources.

The combination of factors surveyed so far-an ambiguous relationship to historical events, the functional obscurity of many details, the lack of discussion in ancient sources—does not mean that monumental reliefs were unimportant to the ancients, only that they did not conceptualize or document them in the same ways as modern scholars. The continued production of monumental reliefs in Rome for centuries indicates that patrons were willing to invest a good deal in the medium. Monumental reliefs, in other words, must have been considered a success. Without written sources, what can we say about how ancient observers interacted with monumental reliefs? One line of physical evidence is ancient alterations of the reliefs. Several reliefs preserve actions taken in response to a historical figure's damnatio memoriae, the repression of public commemoration of an infamous individual (Flower 2011). On the so-called Cancelleria Reliefs (Museo Gregoriano Profano nos. 13389-13391), the original portraits of Domitian were re-cut to those of Vespasian and Nerva (Bergmann 1981), a phenomenon

\footnotetext{
${ }^{2}$ The suggestion that the numismatic designs represent the interior staircase (Claridge 1993, 15; contra Beckmann 2002: 351 n. 14; Elkins 2015: 90 n. 186) is best known from a broader argument of A. Claridge that the frieze is a Hadrianic addition (and therefore could not be depicted on Trajanic coins). Roman die carvers, however, commonly rendered architectural structures abstractly (Elkins 2015; Ritter 2017). From a Roman perspective, it might make sense to privilege a Trajanic staircase over a Trajanic frieze, if the former was deemed more interesting. As Claridge notes, the shapes between the helical lines take the form of lozenges, which resemble the windows of the interior staircase - but are a very peculiar way, I would add, to indicate narrative sculpture, although purposeful multivalence should also be considered.
} 
common in statues as well (Varner 2000). On two Marcus Aurelius Panels, the entire figure of Commodus has been removed. This is especially interesting, since Commodus' condemnation lasted only about three years. These examples reveal that reliefs were not static, but instead were observed and updated to reflect changes in official policy, even if this moved them away from historical fact.

Reliefs could also be moved and repurposed entirely. Starting (probably) in the later third century $\mathrm{CE}$, innovative monuments were created by combining new components with re-used material, both architectural and sculptural. This process, termed spoliation in modern discourse, is not well understood, although the academic bibliography on the subject is vast (Hughes 2014, with bibliography). The Arch of Constantine, probably the best-known example of the practice, combined significant new relief sculpture with older reliefs originally honoring Trajan, Hadrian, and Marcus Aurelius, as well as Trajanic statues of captive Dacians (figure 3).

This Constantinian configuration raises numerous questions that are currently without answers. Is the reliance on sculpture from the so-called "good emperors" meaningful, or just the product of prosperous reigns producing a greater volume of sculpture to be harvested? If the latter, why are there no first century (say Augustan) components? If the selection was meaningful, how would contemporary viewers understand or even recognize the work of earlier reigns, given that all imperial portraits had been re-cut to that of Constantine (figure 2 ) ${ }^{3}$ What was the justification for removing and reusing the sculpture, since at least the Dacian statues came from the Forum of Trajan, an area known to be in use into the fifth century? Why were eight Marcus Aurelius Panels selected for inclusion, while three other panels from the same

\footnotetext{
${ }^{3}$ Early modern scholars removed the Constantinian portraits from the Antonine arch panels, but then replaced them with portraits of Trajan (figure 2), neatly (and unintentionally) illustrating the difficulty of recognizing reliefs from different periods without the guidance of imperial portraiture.
} 
monument were set aside, only to be later preserved in a seventh-century church? One of the few things we can say about spoliation is that it demonstrates that relief sculpture could function at a degree of removal from its original intention, even in the ancient world.

Another line of inquiry is to see how the genre of monumental reliefs was received and employed in the provinces. The few large monuments found outside the capital are eclectic and somewhat erratic, suggesting there was no standardized response to this capital practice. The Sebasteion at Aphrodisias is an interesting, early response to the burgeoning tradition of monumental reliefs in Rome (Smith 2013). A large portico whose primary purpose appears to have been to showcase reliefs praising the imperial family, the Sebasteion shows considerable familiarity with initiatives at Rome. But the execution is hardly identical. The monument's sculptures employ Hellenistic motifs (purely mythological narratives, heroic nudity for emperors) that would have been familiar to a local audience but were foreign to monumental reliefs in Rome. The unparalleled number (190) of relief panels seems an innovation that was never followed elsewhere.

Other monuments drew more directly from the capital. The Fertility Goddess relief from Carthage (Louvre Ma 1838) (figure 7) is clearly based on the equivalent figure on the Ara Pacis (Spaeth 1994). Scale, medium, and the central composition are the same, but the setting and supporting characters have been significantly altered, presumably to answer local needs and concerns. In another example, the Tropaeum Traiani at Adamklissi (Romania) employs much of the same imagery and content found on its contemporary at Rome, the Column of Trajan (Florescu 1965; Coulston 2003) (figures 8-9). Yet the architectural setting-sculptural panels set as large Doric metopes - is not known to have been employed in Rome, despite its long Hellenistic history. Also telling is what imagery is not repeated: while the Roman column 
includes over 300 depictions of architectural structures, none are included in the Tropaeum (although landscape elements are), suggesting that the ideology of the depicted architecture was somehow relevant to a capital, but not provincial, audience.

A third contemporary piece, the Macedonian funerary monument of the Roman officer who captured the suicidal Dacian leader (Speidel 1970), employs the same imagery found on the two large-scale depictions of the event. ${ }^{4}$ Oddly, on the Tropaeum this scene includes a base beneath the horse's feet, suggesting a statue (Florescu no. 28; figure 8). This may reflect not an actual statue, but contemporary coins (e.g. RIC 418 [a]; Woytek 2010, 228) where the groundline resembles a base (cf. Rossi 1997, 480-481). Here we see a situation where monumental reliefs are part of a widespread visual tradition that could be employed in myriad different ways to serve myriad different audiences and purposes.

Indeed, the interaction between monumental reliefs and other artistic genres can be informative. Triumphal paintings, the most commonly cited artistic influence, are not preserved and as such are difficult to assess (Lusnia 2006; Östenberg 2009, 189-215; Wolfram Thill 2018a). The phenomenon of close coincidence in imagery between coins and monumental reliefs reached its florescence under Trajan (Wolfram Thill 2014). Coins also carried images of public statues (figure 4). This demonstrates some level of confluence, either directed or ad hoc, between producers of public sculpture and producers of coins, although we have very little information as to how this might have worked or even who those producers might have been. At the very least the two groups (if separate) were paying attention to the other's activities.

Imagery from monumental reliefs occasionally appears in more private media. The Arch of the Argentarii in Rome was a monument honoring the Severan imperial family (Elsner 2005).

\footnotetext{
${ }^{4}$ The motif of a rider overcoming a fallen enemy is obviously an ancient visual trope. I refer here to the use of this motif to illustrate a particular historical event, namely riding down a Dacian leader.
} 
Although erected in a public space, the arch was commissioned by an association of merchants, not the SPQR. The arch employs much of the same imagery seen in contemporary monumental reliefs (captive barbarians, imperial sacrifice) but on a much smaller scale and in unusual arrangements and configurations. Clearly the Argentarii recognized an arch covered in relief panels as a means of honoring the emperor, but while they took their cues from the senatorial commissions, they did not slavishly reproduce them (although someone did later remove condemned imperial portraits from the arch).

Other pieces have been interpreted as small-scale but direct copies of lost monumental reliefs. The so-called Sorrento Base and related reliefs are thought to be statue bases that reproduced on a reduced scale a lost first-century CE monument (Cecamore 2004). The silver Boscoreale Cups, buried in a villa by the Vesuvian eruption of $79 \mathrm{CE}$, reflect a more private context. Given their use of high relief imagery found in later monumental reliefs, the cups have been interpreted as reproductions of an earlier pre-Flavian monument in Rome (Kuttner 1995). One must be cautious in these cases, however: evoking the genre of monumental reliefs does not necessarily mean direct copying of a single historical model. Circulating in the same elite echelons as silverware, cameos too could include imagery that would eventually appear on monumental reliefs. The "Apotheosis of Claudius" cameo (Paris National Library no. 265) shows the deified emperor riding on an eagle and crowned by a Victory, two motifs that would be employed in separate panels on the (presumably later) Arch of Titus. Examples such as the Boscoreale Cups once again demonstrate that monumental reliefs drew on a shared corpus of imperial imagery that could be employed in numerous media, publically produced to privately owned (Hölscher 1996). 
A final consideration worth exploring here is the idea that written reflections of monumental reliefs may be hiding in plain sight. M. Beckmann $(2011,140)$ has advanced a thought-provoking theory that the fourth-century author of the Historia Augusta may have based his account of the Rain Miracle (SHA Marcus 24.4) on the visuals of the Antonine Column (Scene 34; figure 6). Beyond the particulars of this scene, Beckmann's theory calls to account a prevalent academic bias that privileges texts and treats images as mere supplemental illustrations thereof, even if the images predate the texts considerably. Such a bias presumes that ancient writers never saw or internalized the prominent images in front of them.

Instead, modern scholars need to consider other instances of visual rhetoric influencing the written kind. Two Trajanic examples can be informative. According to one modern theory, both the Column of Trajan and a letter of the younger Pliny (8.4.1ff.) were influenced by Trajan's (lost) written commentaries, since Pliny's letter employs notable motifs—bridges, army camps, landscape descriptions - also found sculpted on the column (Coarelli 2000, 28). But we should question the need to insert a missing written source as an intermediary, since Pliny could have seen the column himself, at least in its initial stages. Similarly, Cassius Dio's late secondcentury accounts of the mysterious mushroom omen delivered to Trajan (68.8.1) could reflect a misunderstanding of the Column's Scene 9 (figure 10), rather than the other way around, as scholars typically suggest (see e.g., Lepper and Frere 1988, 59-60). Given the number, scale, and prevalence of monumental reliefs in Rome, it should not be surprising if ancient writers drew on them for inspiration.

\section{Conclusion}


The Forum of Augustus is famous among classicists for its sophisticated sculptural program, which interwove members of Augustus' family with the mythological and historical founders of Rome. In antiquity the statues were sufficiently well known that copies of some of them were erected in the Forum of Mérida (Spain). Yet by the Flavian period, those same sculptures were referenced in Pompeiian legal documents not as symbols of imperial ideology, but as topographic markers of court locations, akin to an office suite number (Shaya 2013, 90). This spectrum of ancient uses and engagements with sculpture, from the ideological to the mundane, represents a challenge for modern scholars when attempting to understand how public sculpture functioned in the ancient world. Carefully curated modern collections, evenly spaced for optimum viewing in museums, hardly encourage a sense of how ancients experienced sculpture. This challenge comes on top of more logistical issues, from visibility, to preservation bias, to a lack of surety about basic questions of patrons, date, and location for most pieces. Despite these challenges, a fuller understanding of sculptural experience can prove valuable not only for scholars of ancient Rome but of human society in general. Monumental reliefs were immense, permanent billboards advertising the imperial system and seeking to shape viewers' attitudes towards that system. Tensions between historical accuracy and ideological interpretations in ancient reliefs find echoes in modern debates about biased sources of public information. And questions of intended audience, the elite or broader public, can raise issues of class relations that may be familiar today. Methodologies that return the viewer to the study of monumental reliefs have the potential to bear considerable fruit in the years to come. 
Figure List

Figure 1: Tomb of the Haterii, Rome. Illustration of Flavian Amphitheater (Colosseum) (cast in Museum für Abgüsse Klassischer Bildwerke; photo by author).

Figure 2: Lost arch of Marcus Aurelius, Rome. Adventus Panel. Note emperor (with head of Trajan, center) surrounded by divine figures, including Mars (left) and Roma/Virtus (right) (photo by S. Sosnovskiy).

Figure 3: Arch of Constantine, Rome. Northeast corner. Spoiliated sculpture (top to bottom): Antonine panels (see figure 2) framed by Trajanic Dacians, Hadrianic tondos, Constantinian frieze (photo by author).

Figure 4: RIC 418 [a]. Trajanic denarius showing Column of Trajan (Woytek 2010: pl. 104 figure 514-515).

Figure 5: Ara Pacis Augustae, Rome. East mythological panel, showing fertility goddess and other mythological figures (Museo dell'Ara Pacis; photo by author.).

Figure 6: Column of Marcus Aurelius, Rome. Rain god miracle (Scene 16) (photo by author).

Figure 7: Carthaginian relief showing fertility goddess (Louvre Ma 1838; photo by author).

Figure 8: Tropaeum Traiani, Adamklissi. Metope showing Roman horseman (on base?) riding down Dacian leader (Muzeul Arheologic Adamclisi; photo by author).

Figure 9: Column of Trajan. Capture and death of Decebalus (Scene 145) (cast in Museo della Civiltà Romana; photo by author).

Figure 10: Column of Trajan. Mushroom omen (Scene 9) (cast in Museo della Civiltà Romana; photo by author).

Bibliography 
Alexandridis, A. 2004. Die Frauen des römischen Kaiserhauses. Eine Untersuchung ihrer bildlichen Darstellung von Livia bis Iulia Domna. Mainz am Rhein: Philipp von Zabern.

Bartman, E. 1999. Portraits of Livia: imaging the imperial woman in Augustan Rome. Cambridge: Cambridge University Press.

Beckmann, M. 2002. "The columnae coc(h)lides of Trajan and Marcus Aurelius." Phoenix 56: 348-57.

- 2011. The Column of Marcus Aurelius: The Genesis \& Meaning of a Roman Imperial Monument. Chapel Hill, NC: University of North Carolina Press.

Bergmann, M. 1981. "Zum Fries B der flavischen Cancelleriareliefs." Marburger WinckelmannProgramm: 19-31.

Billows, R. 1993. "The religious procession of the Ara Pacis Augustae. Augustus' supplicatio in 13 B.C." Journal of Roman Archaeology 6: 80-92.

Cassibry, K. 2018. "Reception of the Roman Arch Monument." American Journal of Archaeology 122(2): 245-75.

Cecamore, C. 2004. "Le figure e lo spazio sulla base di sorrento." Mitteilungen des Deutschen Archäologischen Instituts, Römische Abteilung 111: 105-41.

Claridge, A. 1993. "Hadrian's column of Trajan?" Journal of Roman Archaeology 6: 5-22.

Clarke, J.R. 2003. Art in the Lives of Ordinary Romans: Visual Representation and Non-Elite Viewers in Italy, $100 B C-A D$ 315. Berkeley: University of California Press.

Coarelli, F. 2000. The Column of Trajan. Rome: Colombo.

- 2008. La Colonna di Marco Aurelio. The Column of Marcus Aurelius. Rome: Colombo.

Coulston, J.C.N. 2003. "Overcoming the barbarian. Depictions of Rome's enemies in Trajanic monumental art." In The representation and perception of Roman imperial power. 
Proceedings of the Third Workshop of the International Network "Impact of empire. Roman empire, c. 200 B.C. - A.D. 476", Netherlands Institute in Rome, March 20 - 23, 2002, edited by L. de Blois, 389-424. Impact of Empire 3. Amsterdam: Gieben.

Dillon, S. 2006. "Women on the Columns of Trajan and Marcus Aurelius and the Visual Language of Roman Victory." In Representations of War in Ancient Rome, edited by S. Dillon and K. Welch, 244-71. Cambridge: Cambridge University Press.

Elkins, N.T. 2015. Monuments in Miniature: Architecture on Roman Coinage. Numismatic Studies Volume 29. New York: American Numismatic Society.

Elsner, J. 1991. "Cult and Sculpture. Sacrifice in the Ara Pacis Augustae." Journal of Roman Studies 81: 50-61.

1995. Art and the Roman Viewer: The Transformation of Art from the Pagan World to Christianity. Cambridge: Cambridge University Press.

_ 2000a. "From the culture of spolia to the cult of relics: the Arch of Constantine and the genesis of late antique forms." Papers of the British School at Rome 68: 149-84.

_.2000b. "Frontality in the Column of Marcus Aurelius." In La colonne Aurélienne. Autour de la colonne Aurélienne. Geste et image sur la colonne de Marc Aurèle à Rome, edited by V. Huet and J. Scheid, 251-64. Bibliothèque de l'École des hautes études. Section des sciences religieuses 108. Turnhout: Brépols.

Elsner, J. 2005. "Sacrifice and narrative on the Arch of the Argentarii at Rome." Journal of Roman Archaeology 18: 83-98.

Ewald, B.C., and C. Noreña, eds. 2010. The Emperor and Rome: Space, Representation, and Ritual. Cambridge: Cambridge University Press.

Fejfer, J. 2008. Roman Portraits in Context. Berlin: De Gruyter. 
Fittschen, K. 1996. "Courtly Portraits of Women in the Era of the Adoptive Emperors (AD 98180) and their Reception in Roman Society." In I Claudia. Women in Ancient Rome, edited by D.E.E. Kleiner and S.B. Matheson, 42-52. 2010. "The portraits of Roman emperors and their families. Controversial positions and unsolved problems." In The Emperor and Rome: Space, Representation, and Ritual, edited by B.C. Ewald, 221-46. Yale Classical Studies 35. Cambridge: Cambridge University Press.

Florescu, F.B. 1965. Das Siegesdenkmal von Adamklissi Tropaeum Traiani. Bonn: Habelt.

Flower, H. 2011. The Art of Forgetting: Disgrace and Oblivion in Roman Political Culture. Chapel Hill, NC: University of North Carolina.

Galinier, M. 2007. La colonne Trajane et les forums impériaux. Collection de l'École française de Rome 382. Rome: L'École française de Rome.

Galinsky, K. 1992. "Venus, polysemy, and the Ara Pacis Augustae." American Journal of Archaeology 96: 457-475.

Gazda, E. 1995. "Roman sculpture and the ethos of emulation. Reconsidering repetition." Harvard Studies in Classical Philology 97: 121-156.

—. 2015. "Domestic Displays." In The Oxford Handbook of Roman Sculpture, edited by E. Friedland, M.G. Sobocinski and E. Gazda, 374-89. New York: Oxford University Press. Gensheimer, M. 2018. Decoration and Display in Rome's Imperial Thermae: Messages of Power and their Popular Reception at the Baths of Caracalla. Oxford: Oxford University Press. Hassel, F.J. 1966. Der Trajansbogen in Benevent. Ein Bauwerk des römischen Senates. Mainz am Rhein: Philipp von Zabern. 
Hölscher, T. 1980. "Römische Siegesdenkmäler der späten Republik." In Tainia. Festschrift für Roland Hampe, edited by H.A. Cahn and E. Simon, 351-71. Mainz am Rhein: Philipp von Zabern.

. 1996. Review of Dynasty and Empire in the Age of Augustus: The Case of the Boscoreale Cups, by A. Kuttner. American Journal of Archaeology 100(4): 800-1. —. 2002. "Bilder der Macht und Herrschaft." In Traian. Ein Kaiser der Superlative am Beginn einer Umbruchzeit?, edited by A. Nünnerich-Asmus, 127-44. Mainz am Rhein: Philipp von Zabern.

- 2004. The Language of Images in Roman Art. Translated by A. Snodgrass and A. Künzl-Snodgrass. Cambridge: Cambridge University Press.

— 2009. "Architectural Sculpture: Messages? Programs? Towards Rehabilitating the Notion of 'Decoration'." In Structure, Image, Ornament: Architectural Sculpture in the Greek World, edited by P. Schultz and R. von den Hoff, 54-67. Oxford: Oxbow. . 2015. "Roman Historical Representations." In A Companion to Roman Art, edited by B. Borg, 34-51. Blackwell Companions to the Ancient World. Malden, MA: WileyBlackwell.

Hughes, J. 2014. "Memory and the Roman Viewer: Looking at the Arch of Constantine." In Memoria Romana: Memory in Rome and Rome in Memory, edited by K. Galinsky. Supplement to MAAR 10. Ann Arbor, MI: University of Michigan Press.

Kellum, B.A. 2015. "Imperial Messages." In The Oxford Handbook of Roman Sculpture, edited by E. Friedland, M.G. Sobocinski and E. Gazda, 423-35. Oxford: Oxford University Press. 
Kovács, P. 2009. Marcus Aurelius' Rain Miracle and the Marcomannic Wars. Mnemosyne Supplements 308. Leiden: Brill.

Kuttner, A. 1995. Dynasty and Empire in the Age of Augustus: The Case of the Boscoreale Cups. Berkeley: University of California Press.

Lancaster, L. 1999. "Building Trajan's Column." American Journal of Archaeology 103(3): 41939.

Leach, E.W. 2006. "Freedmen and immortality in the Tomb of the Haterii." In The art of citizens, soldiers and freedmen in the Roman world, edited by E. D'Ambra and G.P.R. Métraux, 118. BAR-IS 1526. Oxford: Archeopress.

Lepper, F., and S. Frere. 1988. Trajan's Column: A New Edition of the Cichorius Plates. Wolfboro, NH: Alan Sutton Publishing.

Longfellow, B. 2015. "Architectural Settings." In The Oxford Handbook of Roman Sculpture, edited by E. Friedland, M.G. Sobocinski and E. Gazda, 345-57. Oxford: Oxford University Press.

Longfellow, B., and E.E. Perry, eds. 2018. Roman Artists, Patrons and Public Consumption: Familiar Works Reconsidered. Ann Arbor, MI: University of Michigan Press.

Lusnia, S.S. 2006. "Battle Imagery and Politics on the Severan Arch on the Roman Forum." In Representations of War in Ancient Rome, edited by S. Dillon and K. Welch, 272-99. Cambridge: Cambridge University Press.

Madigan, B.C. 2012. The Ceremonial Sculptures of the Roman Gods. Monumenta Graeca et Romana 20. Boston: Brill.

Marlowe, E. 2004. "'That Customary Magnificence which is Your Due': Constantine and the Symbolic Capital of Rome." Ph.D. diss., Columbia University. 
Mazurek, L.A. 2016. "Writing a postmodern art history of classical Italy." Review of Egypt in Italy. Visions of Egypt in Roman Imperial Culture, by M. Swetnam-Burland. Journal of Roman Archaeology 29: 606-12.

Östenberg, I. 2009. Staging the world. Spoils, captives, and representations in the Roman triumphal procession. Oxford: Oxford University Press.

Pfanner, M. 1989. "Über das Herstellen von Porträts: Ein Beitrag zu Rationalisierungsmassnahmen und Produktionsmechanismen von Massenware im späten Hellenismus und in der römischen Kaiserzeit." Jahrbuch des Deutschen Archäologischen Instituts 104: 157-257.

Pollini, J. 2012. "The Ideology of 'Peace through Victory' and the Ara Pacis Augustae." In From Republic to Empire: Rhetoric, Religion, and Power in the Visual Culture of Ancient Rome, 204-70. Norman, OK: University of Oklahoma Press.

Rehak, P. 2001. "Aeneas or Numa? Rethinking the meaning of the Ara Pacis Augustae." The Art Bulletin 83: 190-208.

Ritter, S. 2017. "Buildings on Roman coins: Identification problems." Jahrbuch für Numismatik und Geldgeschichte 67: 101-43.

Rose, C. 1990. "'Princes' and Barbarians on the Ara Pacis." American Journal of Archaeology 94: 453-67.

-1997. Dynastic commemoration and imperial portraiture in the Julio-Claudian Period. Cambridge: Cambridge University Press.

Rossi, L. 1997. "A synoptic outlook of Adamklissi metopes and Trajan's Column frieze. Factual and fanciful topics revisited." Athenaeum 85: 471-86.

Rossini, O. 2012. Ara Pacis: Guide. 3rd ed. Rome: Electa. 
Ryberg, I.S. 1967. Panel Reliefs of Marcus Aurelius. Monographs on archaeology and the fine arts 14. New York: Archaeological Institute of America.

Settis, S. 1988. "La colonna: Strategie di composizione, strategie di lettura." In La Colonna Traiana, edited by S. Settis, A. La Regina, G. Agosti and V. Farinella, 86-255. Saggi 716. Turin: Giulio Einaudi.

Severy, B. 2000. "Family and State in the Early Imperial Monarchy: The Senatus Consultum de Pisone Patre, Tabula Siarensis, and Tabula Hebana." Classical Philology 95(3): 318-37.

Shaya, J. 2013. "The Public Life of Monuments: The Summi Viri of the Forum of Augustus." American Journal of Archaeology 17(1): 83-110.

Smith, R.R.R. 2013. The Marble Reliefs from the Julio-Claudian Sebasteion. Aphrodisias 6. Darmstadt: Philipp von Zabern.

Sobocinski, M.G., and E. Wolfram Thill. 2015. "Monumental Reliefs." In The Oxford Handbook of Roman Sculpture, edited by E. Friedland, M.G. Sobocinski and E. Gazda, 276-91. New York: Oxford University Press.

Spaeth, B.S. 1994. "The Goddess Ceres in the Ara Pacis Augustae and the Carthage Relief." American Journal of Archaeology 98(1): 65-100.

Speidel, M.P. 1970. "The Captor of Decebalus a New Inscription from Philippi." Journal of Roman Studies 60: 142-53.

_.2005-06. "Trajan's Column and the Arch at Benevento." Mitteilungen des Deutschen Archäologischen Instituts, Römische Abteilung 112: 189-206.

Stewart, P. 2003. Statues in Roman Society: Represeantation and Response. Oxford: Oxford University Press. 
- 2008. The Social History of Roman Art. Key Themes in Ancient History. Cambridge: Cambridge University Press.

—.2012. "The Equestrian Statue of Marcus Aurelius." In A Companion to Marcus Aurelius, edited by M. Van Ackeren, 264-77. Oxford: Wiley-Blackwell.

Trimble, J. 2015. "Reception Theory." In The Oxford Handbook of Roman Sculpture, edited by E. Friedland, M.G. Sobocinski and E. Gazda, 606-21. New York: Oxford University Press.

Varner, E., ed. 2000. From Caligula to Constantine: Tyranny and Transformation in Roman Portraiture. Atlanta: Michael C. Carlos Museum.

Warden, P.G. 1991. "The sculptural program of the Villa of the Papyri." Journal of Roman Archaeology 4: 257-261.

Wolfram Thill, E. 2011. "Depicting barbarism on fire: architectural destruction on the Columns of Trajan and Marcus Aurelius." Journal of Roman Archaeology 24: 283-312.

—. 2014. "The Emperor in Action: Group Scenes in Trajanic Coins and Monumental Reliefs." American Journal of Numismatics Second Series 26: 87-140.

—. 2018a. "Don't Confuse Us with the Facts: Visualizing the Frontier in the Capital City." In LIMES XXIII. Proceedings of the 23rd International Congress of Roman Frontier Studies Ingolstadt 2015. Akten des 23. Internationalen Limeskongress in Ingolstadt 2015, edited by C.S. Sommer and S. Matešić, 265-72. Beiträge zum Welterbe Limes Sonderband 4. Mainz: Nünnerich-Asmus Verlag. .2018b. "Setting War in Stone: Architectural Depictions on the Column of Marcus Aurelius." American Journal of Archaeology 122(2): 277-308. 
Wrede, H. 1981. Consecratio in formam deorum : vergöttlichte Privatpersonen in der römischen Kaiserzeit. Mainz am Rhein: Philipp von Zabern.

Zanker, P. 1988. The Power of Images in the Age of Augustus. Translated by A. Shapiro. Jerome Lectures 16. Ann Arbor, MI: University of Michigan Press. 
Figure 1: Tomb of the Haterii, Rome. Illustration of Flavian Amphitheater (Colosseum)

(cast in Museum für Abgüsse Klassischer Bildwerke; photo by author). 


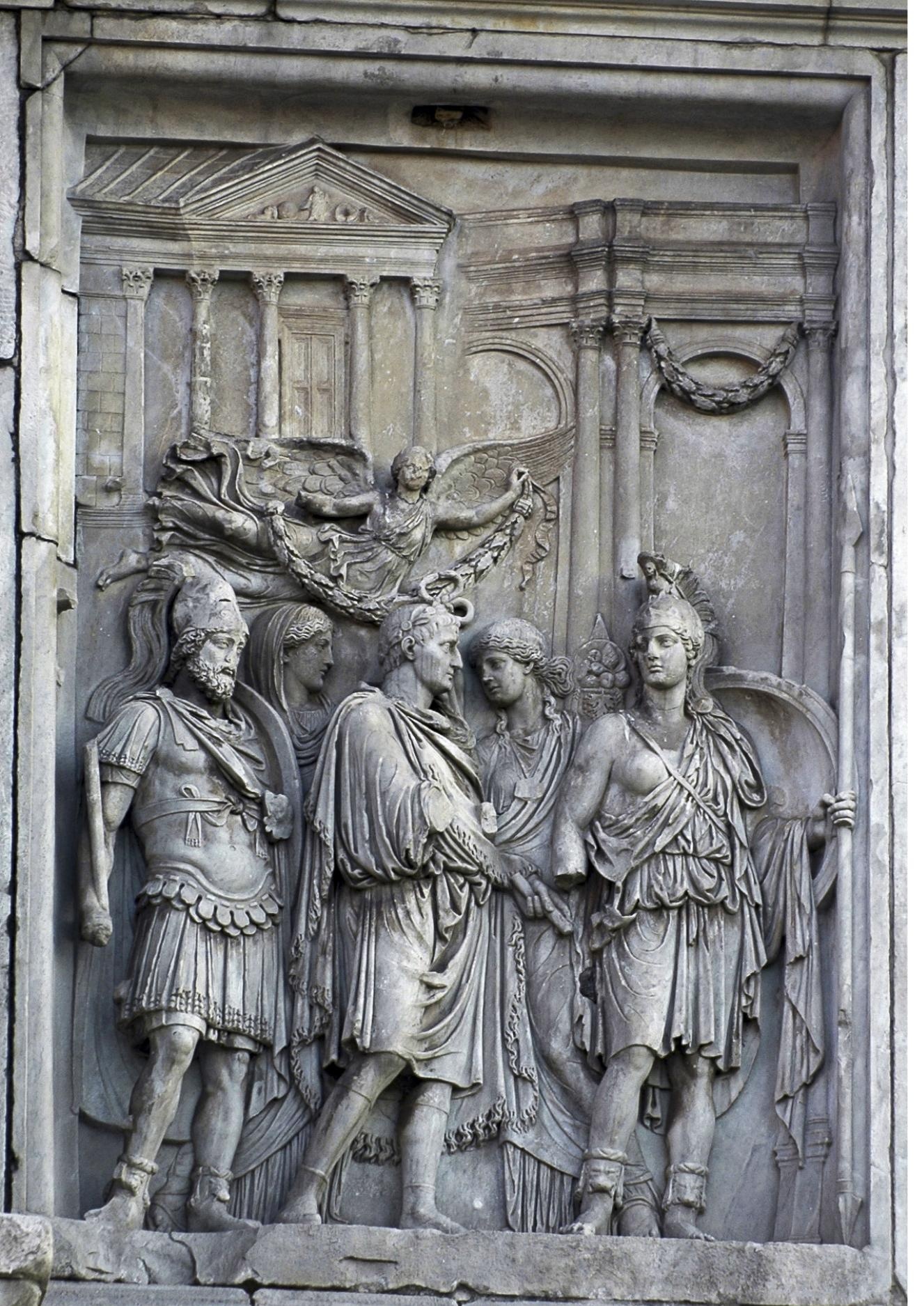

Figure 2: Lost arch of Marcus Aurelius, Rome. Adventus Panel. Note emperor (with head of Trajan, center) surrounded by divine figures, including Mars (left) and Roma/Virtus (right)

(photo by S. Sosnovskiy). 


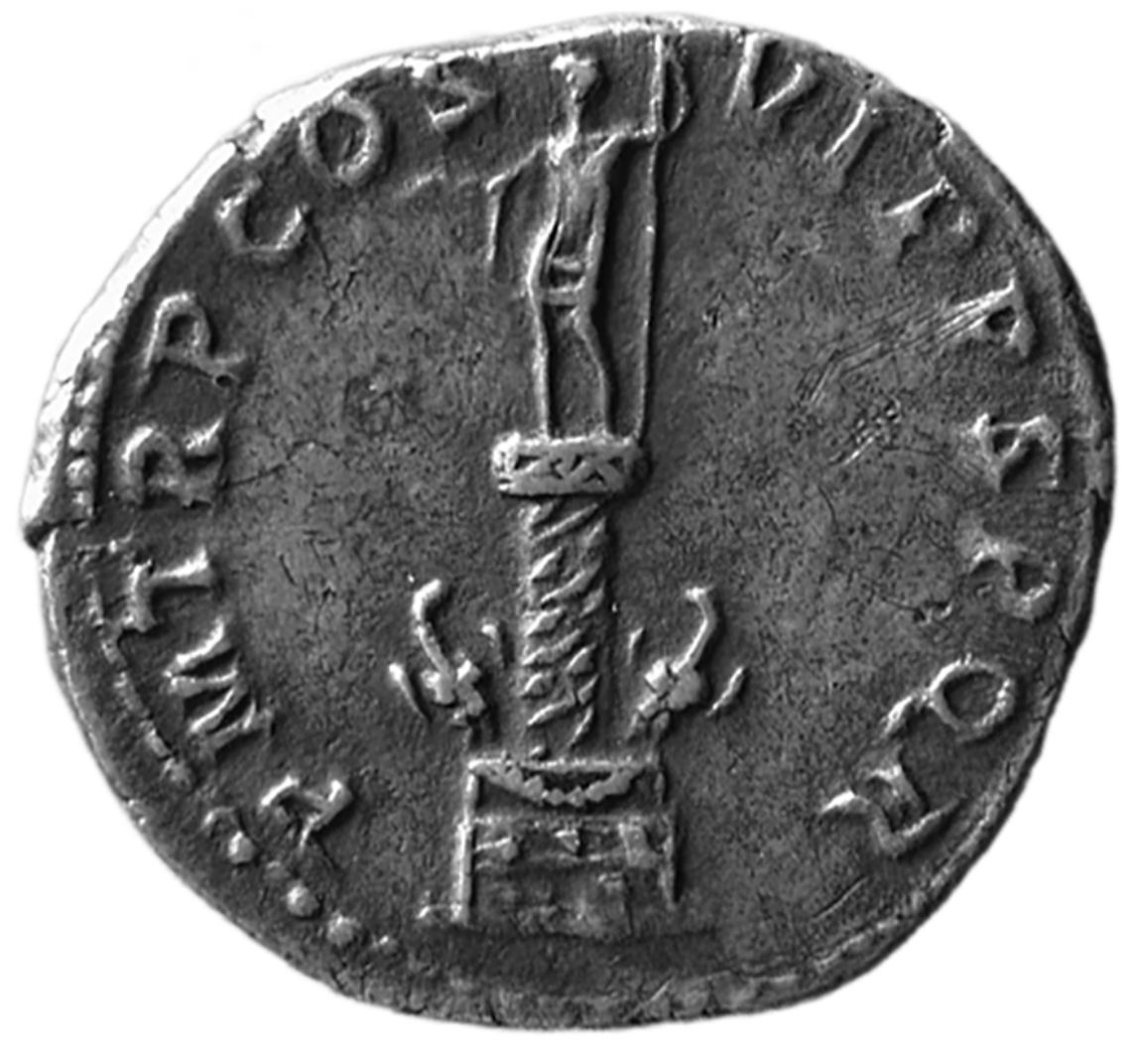

Figure 4: RIC 418 [a]. Trajanic denarius showing Column of Trajan

(Woytek 2010: pl. 104 figure 514-515). 


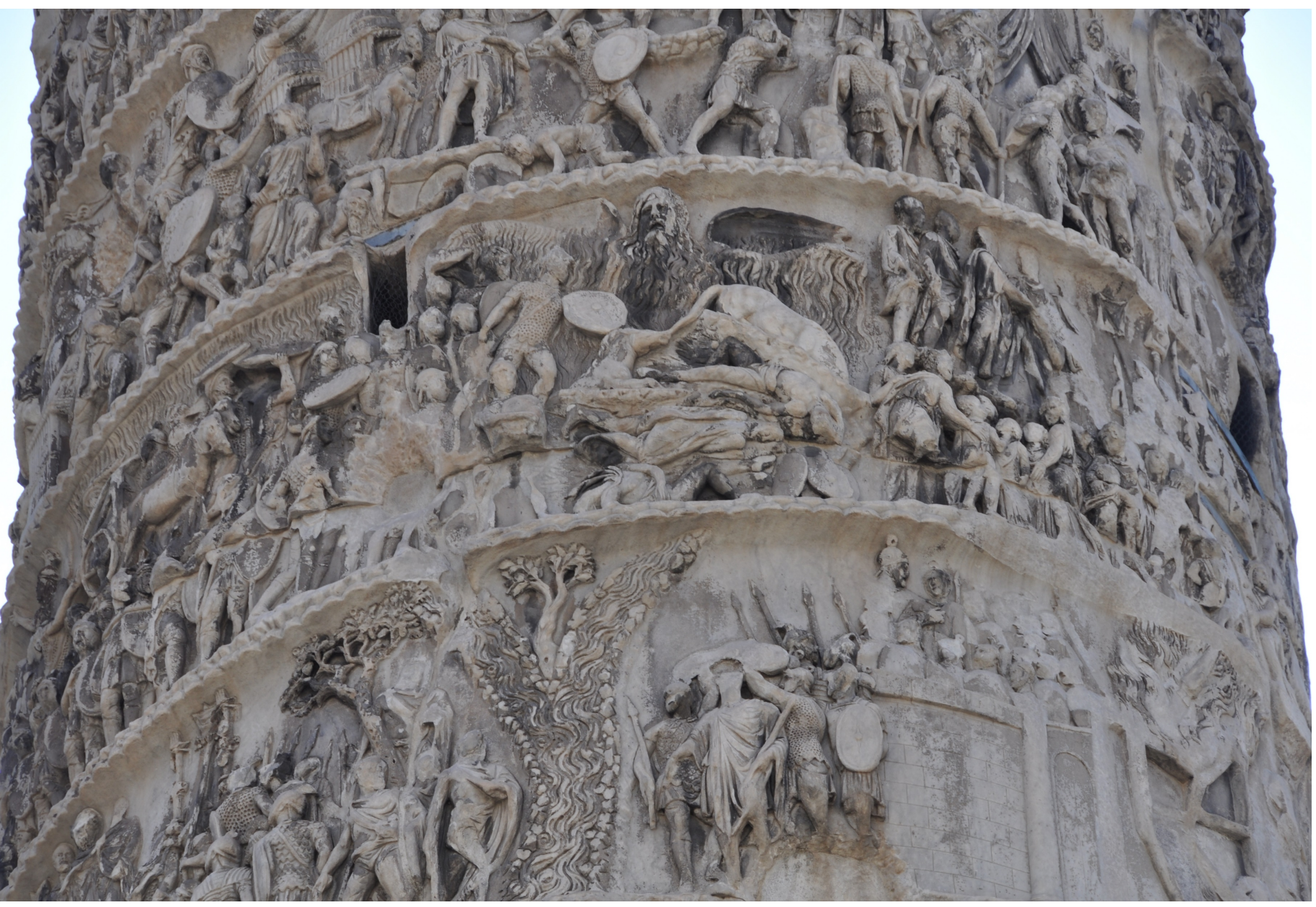

Figure 6: Column of Marcus Aurelius, Rome. Rain god miracle (Scene 16)

(photo by author). 


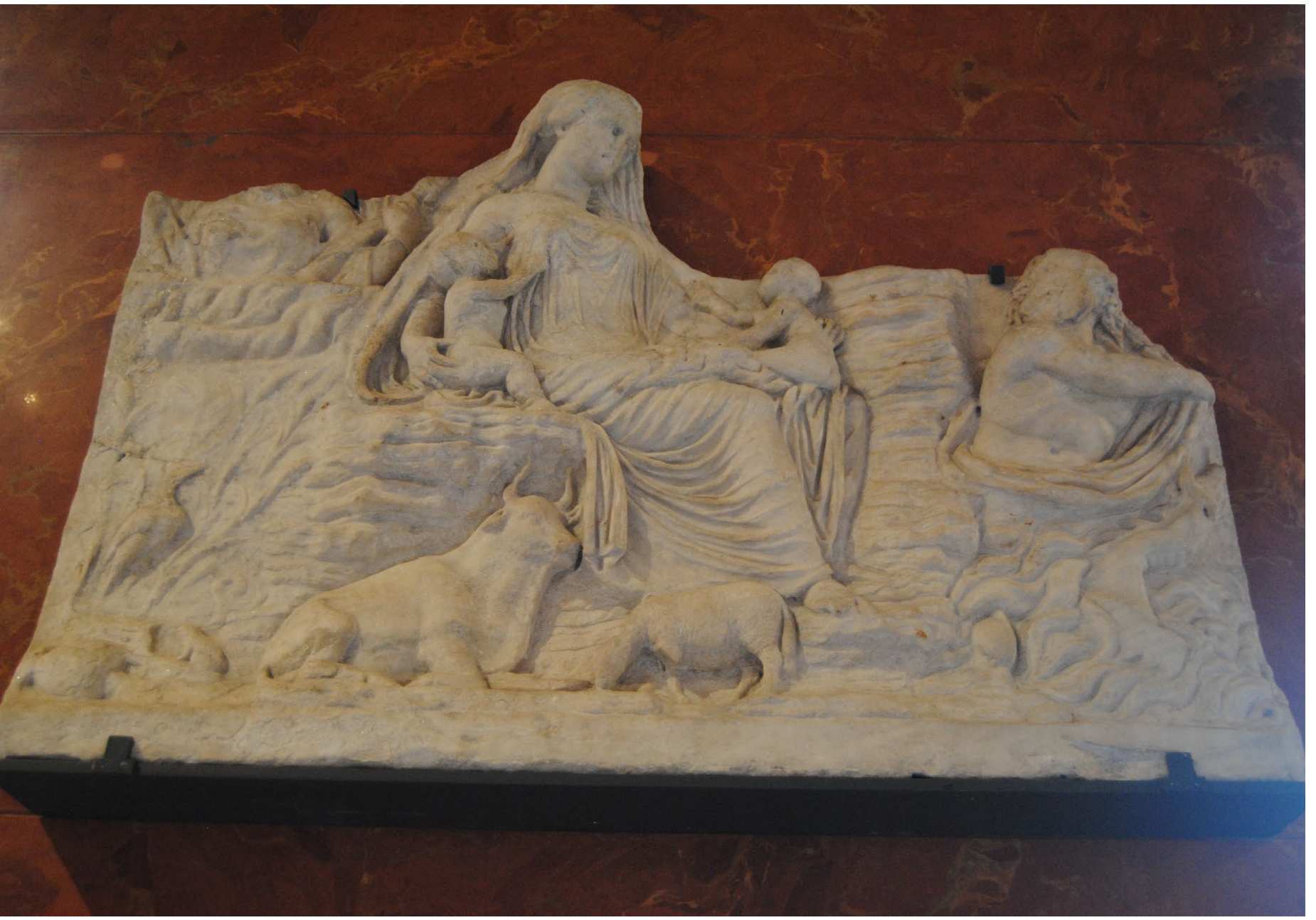

Figure 7: Carthaginian relief showing fertility goddess

(Louvre Ma 1838; photo by author). 
Figure 8: Tropaeum Traiani, Adamklissi. Metope showing Roman horseman (on base?) riding down Dacian leader

(Muzeul Arheologic Adamclisi; photo by author). 


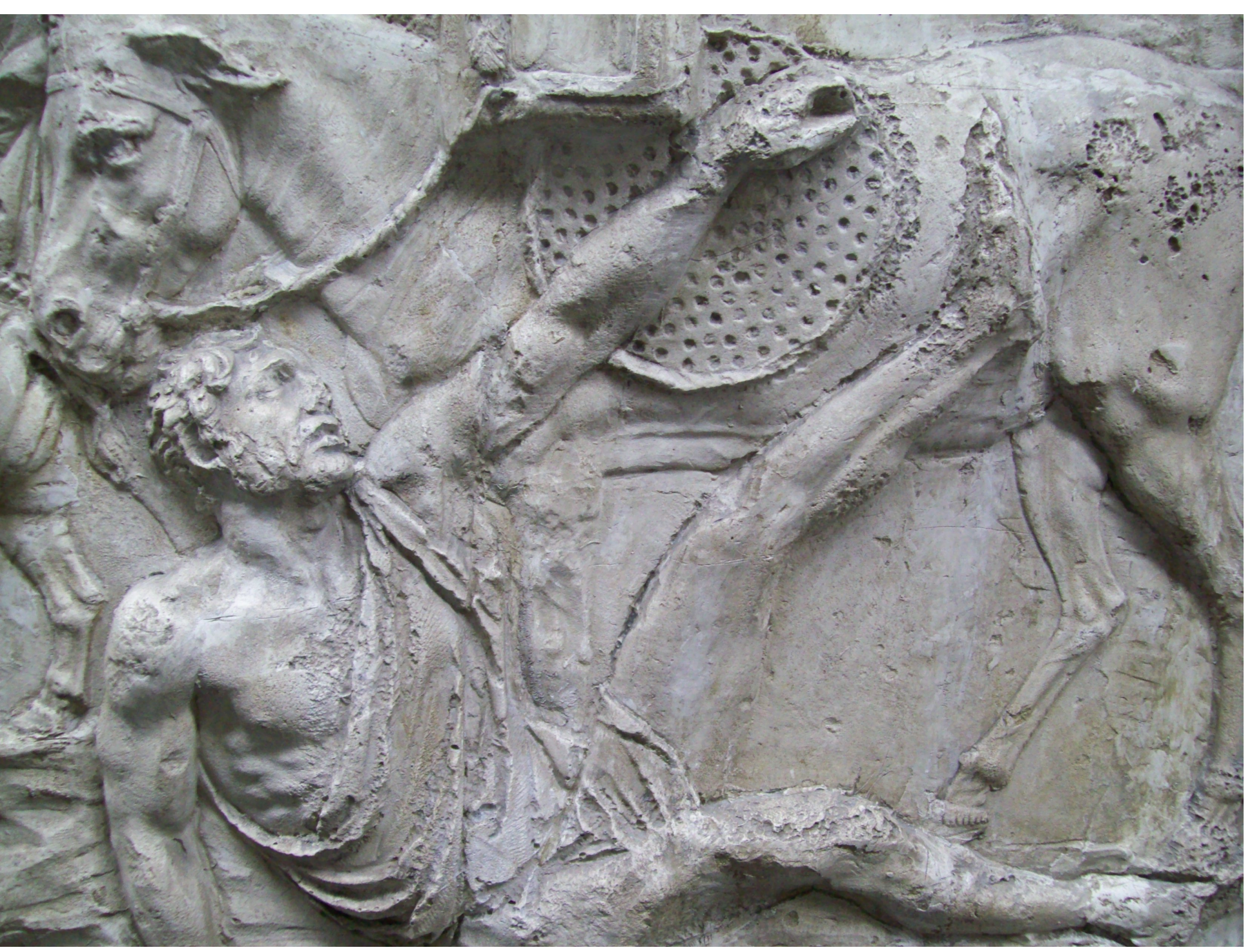

Figure 10: Column of Trajan. Mushroom omen (Scene 9)

(cast in Museo della Civiltà Romana; photo by author). 